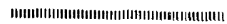

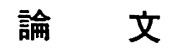

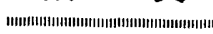 \\ 高炉軟化融着帯の溶解に関する検討*

\author{
研野 雄二***. 須賀田正泰**. 安倍 勲*** \\ 山口 一良**.中村展**
}

\section{Investigation of Melt-down of Softening-Melting Zone in Blast Furnace}

Yuji Togino, Masayasu Sugata, Isao ABE,

Kazuyoshi Yamaguchi, and Makoto Nakamura

\begin{abstract}
Synopsis :
Melt-down mechanism of softening-melting layers in Hirohata No. 1 BF (blast furnace) is examined. As the results with the upper part of "root" (the lower part of softening-melting zone, the end of which contacts with the furnace wall), heat of fusion is considered to depend on the reduction rate (R.R.) of softening-melting layer. The values are about $3 \times 10^{3} \mathrm{kcal} / \mathrm{t}$-softening-melting layer with R.R. $\sim 50 \%, 8 \times$ $10^{3} \mathrm{kcal} / \mathrm{t}$ with R.R. $\sim 70 \%$ and $31 \times 10^{3} \mathrm{kcal} / \mathrm{t}$ with R.R. $>70 \%$. From these values and calculated meltdown volume at "root" of Hirohata No. 1 BF, heat transfer coefficient for melt-down of "root" is obtained. By applying the relation to the estimated softening-melting zone in Kimitsu No. 3 BF, melt-down volume agrees approximately with the heat transfer quantity. Melt-down of inverse $\mathrm{V}$-shaped softening-melting zone is concluded to occur by this mechanism.
\end{abstract}

1. 緒

\section{言}

近年我が国で高炉の内部状態を正確に知り，原料性状 の改善, 高炉の設備, 操業の改善に役立たせるために, 高炉を操策中の状態で吹止め解体調査することが数多く 行われている1) -9). この結果数多くの知見が得られてき ている(10)が，これらのらち炬内状況に関する最も顕著な ものは, 軟化融着帯の存在である.この軟化融着帯の意 義については，発見当初から論議され，モデル実験等に よつてその形状と通気抵抗やガス分配の関係が調べられ て来た 2)、筆者らは，前報11)に拈いて広畑 1 高炉の解体 時の軟化融着帯のガス分配を表わす数式モデルを作成 し，これによつて軟化融着带のガス分配と軟化・溶解量 が関係することを見出した.ささらに軟化融着帯根部の溶 解が円周方向で異なり, 一部は炉中心迄残存している原 因について検討し主として羽ロごとの風量差に起因する ことを報告した（根部とは融着带下部の部分で融着帯が 炉壁に接している部分をいら). さらにこのモデルによ つて高炉にとつて望ましい融着带形状（以下計算に用い
た軟化融着带を融着带と呼ぶ）は, 融着帯の安定性やガ 又利用率の点から内部形状が炉中心に近付いた型（融着 带下部が内部に張出した型）が望ましいことを述べた。

本報においては，前報の結果をもとに融着帯形状が， 高炉操業にどのような意味があるかを解明し，との形状 を適切なものに制御する可能性を知るために融着帯の溶 け落ち機潇について検討した結果を報告する。検討は， 根部より上の部分と根部に分けそれぞれ融着層の溶解機 構を設定し解析を行つた。なお軟化融着帯の各部の名称 については次のよらに定義した（詳細は前報11)参照).

軟化融着帯頂層 : 逆V字型の軟化融着帯の最上層 軟化融着带根部：軟化融着帯下部の炉壁に接している 軟化融着層

層幅 : 軟化融着層の一層の幅

$$
\text { コークス・スリット：軟化融着層にはさまれたコーク }
$$
又層

外部形状・内部形状 : 軟化融着带の内側および外側の 形状

* 昭和 52 年 4 月本会誹演大会にて発表 昭和 53 年 7 月 10 日受付 (Received July 10, 1978)

** 新日本製鉄 (株) 君津製鉄所 (Kimitsu Works, Nippon Steel Corp., 1 Kimitsu Kimitsu 299-11)

*** 新日本筊鉄 (㧣) 本社 (Nippon Steel Corp.) 
Table 1. Operating results of Hirohata No. 1 blast furnace before blow-down on July 23, 1970.

\begin{tabular}{c|c|c|c|c|c|c}
\hline Data & $\begin{array}{c}\text { Production } \\
(\mathrm{t}-\mathrm{Fe} / \mathrm{day})\end{array}$ & $\begin{array}{c}\text { Slag Volume } \\
(\mathrm{t} / \mathrm{t}-\mathrm{Fe})\end{array}$ & $\begin{array}{c}\text { Blast Volume } \\
\left(\mathrm{Nm}^{3} / \mathrm{min}\right)\end{array}$ & $\begin{array}{c}\text { Blast Temp. } \\
\left({ }^{\circ} \mathrm{C}\right)\end{array}$ & $\begin{array}{c}\text { Humidity } \\
\left(\mathrm{g} / \mathrm{Nm}^{3}\right)\end{array}$ & $\begin{array}{c}\mathrm{O}_{2} \text { enrich } \\
(\%)\end{array}$ \\
\hline July 20 21 & 2550 & 0.289 & 2300 & 954 & 32.0 & 0.96 \\
\hline & $\begin{array}{c}\text { Coke Ratio } \\
(\mathrm{kg} / \mathrm{t}-\mathrm{p})\end{array}$ & $\begin{array}{c}\text { Oil Ratio } \\
(\mathrm{kg} / \mathrm{t}-\mathrm{p})\end{array}$ & $\begin{array}{c}\text { Sinter Ratio } \\
(\%)\end{array}$ & $\begin{array}{c}\text { Pellet Ratio } \\
(\%)\end{array}$ & $\begin{array}{c}\text { Number of Charge } \\
(\text { Number/day })\end{array}$ & $\begin{array}{c}\text { Calculated } \\
\text { Flame Temp } \\
\left({ }^{\circ} \mathrm{C} \text { at } 145 \phi \mathrm{OT}\right)\end{array}$ \\
\hline & 507 & 37 & 50.4 & 15.2 & 104 & 2066 \\
\hline
\end{tabular}

Table 2. Dimension and calculated coke slit gas volume with softening-melting zone of dissected Hirohata No. I blast furnacei1).

\begin{tabular}{|c|c|c|c|c|c|c|}
\hline No. of layer & $\begin{array}{l}\text { Coke slit } \\
\text { gas volume } \\
(\mathrm{kg} / \mathrm{h})\end{array}$ & $\begin{array}{l}\text { Inside radius } \\
(\mathrm{m})\end{array}$ & $\begin{array}{c}\text { Outside radius } \\
(\mathrm{m})\end{array}$ & $\begin{array}{c}\text { Thickness of } \\
\text { cohesive layer }(\mathrm{m})\end{array}$ & $\begin{array}{l}\text { Thickness of } \\
\text { coke layer }(\mathrm{m})\end{array}$ & $\begin{array}{l}\text { Melt-down } \\
\text { volume }\left(\mathrm{m}^{3}\right)\end{array}$ \\
\hline $\begin{array}{c}3 \\
4 \\
5 \\
6 \\
7 \\
8 \\
9 \\
10 \\
11 \\
12 \\
13 \\
14 \\
15 \\
16 \\
17\end{array}$ & $\begin{array}{l}4.74 \times 10^{3} \\
8.57 \\
8.98 \\
7.34 \\
7.14 \\
7.34 \\
7.35 \\
10.20 \\
13.06 \\
16.33 \\
21.23 \\
25.71 \\
27.35 \\
27.35 \\
31.84\end{array}$ & $\begin{array}{l}0.61 \\
0.69 \\
0.91 \\
1.16 \\
1.21 \\
1.26 \\
1.31 \\
1.35 \\
1.43 \\
1.51 \\
1.57 \\
1.69 \\
1.72 \\
1.74 \\
1.89\end{array}$ & $\begin{array}{l}1.65 \\
1.88 \\
2.10 \\
2.23 \\
2.35 \\
2.60 \\
2.85 \\
3.18 \\
3.35 \\
3.58 \\
3.81 \\
4.03 \\
4.26 \\
4.48 \\
4.80\end{array}$ & $\begin{array}{l}0.25 \\
0.30 \\
0.31 \\
0.27 \\
0.28 \\
0.28 \\
0.28 \\
0.30 \\
0.30 \\
0.28 \\
0.26 \\
0.24 \\
0.22 \\
0.20 \\
0.22\end{array}$ & $\begin{array}{l}0.49 \\
0.44 \\
0.40 \\
0.36 \\
0.30 \\
0.26 \\
0.26 \\
0.26 \\
0.26 \\
0.25 \\
0.25 \\
0.24 \\
0.20 \\
0.16 \\
0.16\end{array}$ & $\begin{array}{l}0.08 \\
0.33 \\
0.50 \\
0.10 \\
0.11 \\
0.11 \\
0.09 \\
0.21 \\
0.22 \\
0.16 \\
0.32 \\
0.08 \\
0.05 \\
0.34 \\
0.11\end{array}$ \\
\hline 18 & 0 & 1.93 & 5.13 & \multicolumn{3}{|c|}{ The highest layer of "root" } \\
\hline
\end{tabular}

\section{2. 根部より上部の軟化融着帯の溶け落ち 機構と溶解熱の検討}

広畑解体 1 高炉の操業条件および解体時の軟化融着帯 形状から計算した各コークス・スリット層を通るガス分 配量および溶け落ち量から融着帯上部の層の溶解熱を計 算する. 吹止め時の操業条件および前報の結果をTable 1,2 に示す.

\section{$2 \cdot 1$ 軟化融着带の溶け落ちモデル}

\section{$2 \cdot 1 \cdot 1$ モデルの仮定と関係式}

広畑 1 高炉の解体時の軟化融着層の状態をみると 2) 装入された鉱石層は，降下寸るに従つて中心から軟化融 着が始まつている，さらに降下寸ると中心部から溶计落 ちが起こり，全体が円環状の軟化融着層になる，軟化融 着層の一層については, 炉壁に近い部分は, 鉱石同志が ゆるく固着したのみの状態であり，ガスの通過も容易と 思われるが，炉中心の先端に近付くにつれて鉱石同志の 一体化が進み，空隙率も減少しがスが通過し難い状態に なつている，そして融着層の溶解は，層の先端部から起 こつている，特に頂層に近い融着風の場合, 融着層の上
側は, 温度が低いためか還元, 融着の度合が低い状態に ある。このためガスは, 炉中心の滴下带から融着層の先 端で層の中を通過するよりもコークス層を横に流れ，融 着の進行の少ないところに来て上部に流れるものと推定 される，そこで次のよらに溶将ちの機構を仮定した。

(仮定)

（1）注目した融着層については是似的に定常状態に なつている. ガスは, 炉中心から水平に融着層間のュー クス層を流れ，この層中のコークスと熱交換して塊状帯 に出る、ュークス層は，一層の上下の温度差はないと考 え, ある一定時間（装入間隔に等しい時間）後に熱収支 に従つた熱量が与えられ一層下の層に移る。

（2）融着層の溶け落ち温度は一定としガスからの伝 熱によつて溶け落ちる. ガスから融着層への溶け落ちに 使われる熱の伝達は, 融着層の下側からのみについて考 虑する.この仮定については，次のことから決めた。す なわち，伝熱は上側からもあるが，実際の融着層の状態 は，下側に比べて還元状態が低いこと，粒子の融着状態 が弱いこと, 特に溶け落ちが上側で起こつているように は見えないことから下からの伝熱のみが溶け落ちに使わ 
れるとした。

（3）伝熱は，充填層の管壁への伝熱と同じィカニズ 么と考え, 熱伝達を総括伝熱係数を使つて表現する. 戦 密にいえば，この総括伝熱係数を対流层熱と放射伝熱に 分離して考虑する必要がある. 今回は省略した。

（4）固体は上から下にガスは横方向に移動する（十 字流).

Fig. 1 にこれらの仮定にしたがつた模式図を示した。 模式図にしたがつて $1 \mathrm{~h}$ 当たりの熱䔟動を考えると，あ る融着層について中心からrの位置の $d r$ の幅を考劣 の移動量を考えると次の式が成立する，ガスからコーク ス一の熱移動量 $d Q_{1}$ は,

$$
d Q_{1}=+h_{\mathrm{p}} \cdot A_{\mathbf{0}} \cdot\left(2 \pi r \cdot d r \cdot l_{\mathrm{c}}\right)\left(t_{\mathrm{g}}-t_{\mathrm{s}_{0}}(r)\right)
$$

同時にガスから融着層に移行する熱量 $d Q_{2}$ は,

$$
d Q_{2}=h_{\mathrm{w}} \cdot\left(t_{\mathrm{g}}-t_{\mathrm{m}_{0}}\right) \cdot 2 \pi r \cdot d r \quad \text { となる. }
$$

一方熱収支から装入間瀜の時間内に出いて初如に $t_{\mathrm{s}}$ (r) であつたコークスが，一層降下する間に $t_{\mathrm{S}_{1}}(r)$ に上 昇するとすれば，固体(コークス) 側について受熱量 $d q$ は,

$$
d q=\rho_{\mathrm{c}} \cdot l_{\mathrm{c}} \cdot 2 \pi r \cdot d r \cdot C_{\mathrm{c}} \cdot\left(t_{\mathrm{s}_{1}}(r)-t_{\mathrm{s}_{0}}(r)\right)
$$

$1 \mathrm{~b}$ 当たりの装入回数を $n$ とすると $n \cdot d q$ は，疑似定常 状態の仮定から $n \cdot d q=d Q_{1}$, またガス側については， $d Q=d Q_{1}+d Q_{2}$ となる. 固体側について同樣に次式が成 立つ.

$$
\begin{aligned}
& n \cdot \rho_{\mathrm{c}} \cdot l_{\mathrm{c}} \cdot 2 \pi r \cdot d r \cdot C_{\mathrm{c}} \cdot\left(t_{\mathrm{s}_{1}}(r)-t_{\mathrm{S}_{0}}(r)\right) \\
& \quad=h_{\mathrm{p}} A_{0} \cdot\left(2 \pi r \cdot d r \cdot l_{\mathrm{c}}\right)\left(t_{\mathrm{g}}-t_{\mathrm{s}_{0}}(r)\right) \cdot \cdots
\end{aligned}
$$

今も乙 $\left(t_{\mathrm{s}_{1}}(r)-t_{\mathrm{s}_{0}}(r)\right), t_{\mathrm{s}_{0}}(r)$ が既知であれば，ガス の温度 $t_{\mathrm{g}}$ は,

$$
t_{\mathrm{g}}=t_{\mathrm{s}_{0}}(r)+n \cdot \rho_{\mathrm{c}} \cdot C_{\mathrm{c}} \cdot\left(t_{\mathrm{s}_{0}}(r)-t_{\mathrm{s}_{0}}(r)\right) / h_{\mathrm{p}} \cdot A_{0} \cdots(2)
$$

で求められる．またガスから融着層一の熱移動量は， $t_{\mathrm{g}}$ が $t_{\mathrm{m}_{0}}$ になる位置 $r_{\mathrm{m}_{0}}$ がわかれば，

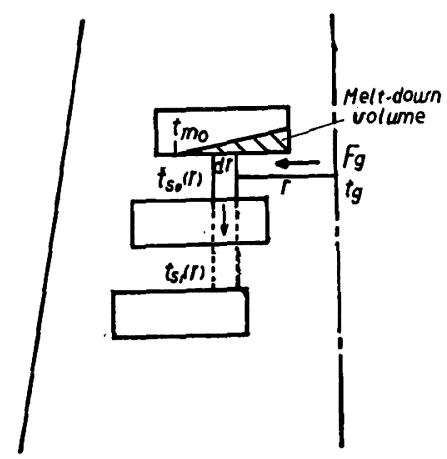

Fig. 1. Schematic view of heat transfer from gas to softening-melting layer.

$$
\int_{r_{0}}^{r_{\mathrm{m}_{0}}} h_{\mathrm{w}} \cdot\left(t_{\mathrm{g}}-t_{\mathrm{m}_{0}}\right) \cdot 2 \pi r \cdot d r
$$

から求めることができる.

$2 \cdot 1 \cdot 2$ 計算に用いる各数值の推定

$2 \cdot 1 \cdot 2 \cdot 1$ 融着層間ュークスの温度の推定

広烟 1 高炉の解体時の温度分布（コークス黒鉛化の程 度から求めたもの) (Fig. 2) から融着層間のコークス温 度を推定すると Table 3 に示すようになる．この値は， コークス・スリット内のコークス温度の推定可能な融着 㢖の第 12 層から第 16 層のところから求めた. Table 3 から融着層の先端之 $1 \mathrm{~m}$ 後では約 $100^{\circ} \mathrm{C}$ の差がある. 広畑 1 高炉の解体時の温度の推定に用いたュークス黒鉛 化法は，昇温スピード, 銑鉄の存在などのため, 求められ た温度は，実際よりも $100 \sim 150^{\circ} \mathrm{C}$ 低いと推定されるこ とや，温度の低い時は黒鉛化の程度を測定するX線の半 価幅の変化が少ないため䛊差が大きくなる．ここでは温 度差について相対的な関係は，絶対値に関係なく正しい と考えて融着層先端のコークス温度は, $1475^{\circ} \mathrm{C}, 1 \mathrm{~m}$ 後 では $1375^{\circ} \mathrm{C}$ と考光だ. 次に融着增内のコークス温度と 径との関数関係については，Fig. 2 の根部付近の温度分 布から推定した. 結果は, $\log \left(t_{\mathrm{S}_{0}}(r)\right)$ は $r^{2}$ に比例する 関係が得られたので，同一の関係を他のコークス・スリ ット層内にも適用できるとして $t_{\mathrm{s}_{0}}(r)$ を推定した。推定 した式は，

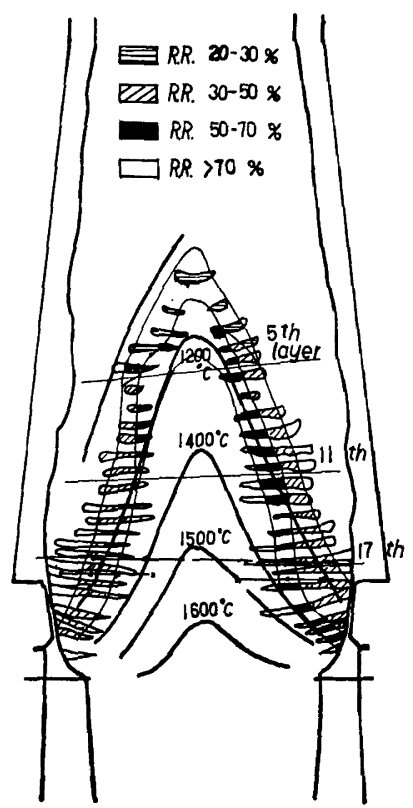

Fig. 2. Distribution of reduction degree and temperature in Hirohata No. 1 blast furnace. 
Table 3. Coke temperature in softening-melting zone of dissected Hirohata No. 1 blast furnace.

\begin{tabular}{|c|c|c|c|c|}
\hline \multirow{2}{*}{$\begin{array}{l}\text { No. of } \\
\text { layer }\end{array}$} & \multicolumn{3}{|c|}{ Coke temperature under a softening-melting layer } & \multirow{2}{*}{$\begin{array}{l}\text { Coke temperature } \\
\text { difference between } \\
\text { two layer }\end{array}$} \\
\hline & The point $\left({ }^{\circ} \mathrm{C}\right)$ & $\begin{array}{l}\text { One meter away } \\
\text { from the edge }\left({ }^{\circ} \mathrm{C}\right)\end{array}$ & Difference & \\
\hline $\begin{array}{c}10 \\
11 \\
12 \\
13 \\
14 \\
15 \\
16 \\
\text { Mean }\end{array}$ & $\begin{array}{c}- \\
\overline{13} \\
1320(1320)^{*} \\
1360 \\
1320(1330) \\
1300(1410) \\
1326\end{array}$ & $\begin{array}{cc}- & - \\
1200 \\
1250(1210) \\
1250 \\
1210(1250) \\
1190(1330) \\
1225\end{array}$ & $\begin{array}{c}- \\
\overline{100} \\
70(110) \\
110 \\
110(80) \\
110(80) \\
101 \fallingdotseq 100^{\circ} \mathrm{C}\end{array}$ & $\begin{array}{l}25.5 \\
30.0 \\
28.5 \\
23.6 \\
22.2 \\
23.4 \\
25.4\end{array}$ \\
\hline
\end{tabular}

* The form shows temperature difference of right side, (left sidw) of softening-melting zone in Fig. 2.

$$
\begin{aligned}
& \log t_{\mathrm{S}_{0}}(r)=\left(0.0304 /\left(r_{0}^{2}-r_{1}^{2}\right)\right) \cdot r^{2} \\
& \quad+\left(3.138 \cdot r_{0}{ }^{2}-3.169 \cdot r_{1}{ }^{2}\right) /\left(r_{0}{ }^{2}-r_{1}^{2}\right)
\end{aligned}
$$

である.

\section{$2 \cdot 1 \cdot 2 \cdot 2$ 融着層一層の違いによる温度差}

一層ごとの温度差 $J t_{\mathrm{S}}\left(\equiv t_{\mathrm{S}_{1}}(r)-t_{\mathrm{s}_{0}}(r)\right)$ については, Fig. 2 の各融着層間ュークスの温度差を求めればよい. Table 3 に融着層先端に打ける温度勾配から求めた值を 載せた。 $\Delta t_{\mathrm{s}}$ の值は，融着帯の下部になるにつれて小さ くなつているが，ここでは平均値の $25.4^{\circ} \mathrm{C} /$ 層を採用 寸る.

$2 \cdot 1 \cdot 2 \cdot 3$ 広畑 1 高炉解体時の融着層の溶け落ち温度 広畑 1 高炉の軟化融着帯の滴下実験によれば12)， スラ グとメタルの溶け落ち温度の差はほとんどないが，昇温 速度と関係があり昇温速度 $2^{\circ} \mathrm{C} / \mathrm{min}$ のとき $1430^{\circ} \mathrm{C}$, $4^{\circ} \mathrm{C} / \mathrm{min}$ のとき $1475^{\circ} \mathrm{C}$ であつた。さて炉内に打いて 軟化融着層がどのくらい昇温速度になつているかは次の よらにして求めた，解体高炉の融着層ごとの平均装入間 隔がわかつていることおよび炬内のコークス温度分布が 推定されていることから, ある融着層近傍の場所から垂 直に降下させ何層目でュークス温度がどのくらい上がつ たかから昇温速度を計算した.融着層の第 6 層(第 10 層) の先端位置から $200^{\circ} \mathrm{C}\left(150^{\circ} \mathrm{C}\right)$ の温度上昇があるところ を求めると Fig. 2 の左側の部分と右側の部分について, それぞれ第 15 層目, 第 13 層目 (平均 8 層で $200^{\circ} \mathrm{C}$ 上昇) (および第 19 層目 (平均 9 層で $150^{\circ} \mathrm{C}$ 上昇)）となる. 平竘装入間隔は，13.85 分なので昇温スピードは $1.8^{\circ} \mathrm{C}$ $/ \mathrm{min},\left(1.2^{\circ} \mathrm{C} / \mathrm{min}\right)$ である. 平均 $1.5^{\circ} \mathrm{C} / \mathrm{min}$ の時の 溶け落ち温度は, 前記の実験結果から昇温スピードと溶 け落ち温度が比例するとして，1420 $\mathrm{C}$ に決めた。

\section{2 触着層の溶解熱の計算}

前節の推定値のほか，総括伝熱係数 $h_{\mathrm{w}}$ については, 葛岡の式, $h_{\mathrm{p}}$ については Ranz の式を用いる.

$$
h_{\mathrm{w}}=0.62\left(\lambda_{\mathrm{g}} / D_{\mathrm{T}}\right) \cdot\left(D_{\mathrm{T}} \cdot G / \mu_{\mathrm{f}}\right)^{0.7} \cdot\left(C_{\mathrm{p}} \cdot \mu_{\mathrm{f}} / \lambda_{\mathrm{g}}\right)^{1 / 3}
$$

$$
\begin{aligned}
& h_{\mathrm{p}}=\left(k_{\mathrm{f}} / d_{\mathrm{s}} \phi_{\mathrm{s}}\right)\left\{2.0+0.6\left(9 \times\left(d_{\mathrm{s}} \phi_{\mathrm{s}}\right) G / \mu_{\mathrm{f}}\right)^{1 / 2}\right. \\
& \left.\cdot\left(C_{\mathrm{p}} \cdot \mu_{\mathrm{f}} / k_{\mathrm{f}}\right)^{1 / 3}\right\}
\end{aligned}
$$

上式および(4)式を(2)式に代入し $t_{\mathrm{g}}=1420^{\circ} \mathrm{C}$ にな る位置 $r_{\mathrm{m}_{0}}$ を求め, この值と(2) 式から(3) 式を用いて, 注目している融着層の $\mathrm{Ih}$ 当染りの熱移行量を知ること ができる．実際には，これらの $r_{\mathrm{m}_{0}}$, 熱移行量を求める ことは容易でないので数值計算によつて求めた. 得られ た結果を Table 4 に示す。この值から融着層単位重量 あたりの見掛け溶解熱を計算するある層から次の層に移 る時の溶け落ち量を $v$ とすると $1 \mathrm{~h}$ 当たりの溶け落ち量 は, $n \cdot v \cdot \rho(\mathrm{t} / \mathrm{h}) . n$ は広烟解体高炉の場合 $1 \mathrm{~h}$ 当たりの 装入回数で 4.33 である.

融着凮の密度については，次のように計算する．広畑 1 高炉の解体時での鉱石層の層厚が半径方向で均一であ るとすると, 根部で溶け落ちる量とそれ以上で溶け落ち る量の比は, 根の最上層での残存融着層面積と全断面積 の比になる (Table 2 から $\{(5.13 \sim 1.93) / 5.13\}^{2}=$ 0.858)．実際は，装入された鉱石層は，降下寸るにつれ て炉径の抁大と共に断面積に比例して層が薄くなる.し かし一旦融着した部分は塊状層のようには炉壁径の拡大 に伴つて扗大できない，装入された鉣石層は，降下する に従い中心から融着層になるが，この時の径の拡大に伴 つて扗大するのは, 残つた鉱石層が引き受けるので, こ こでは頂層の炉壁径と根最上層の炉壁径の半分の位置で の鉣石層の比率が根部で成立すると仮定する.このよう に考えるとFig. 3 に示すごとく根部以上で溶解した面積 (量) 比は $(1.93 / 4.5)^{2}=0.183$ になる.

吹止め前の平均鉄生産量は, $2550 \mathrm{t} / \mathrm{d}$, スラグ比 0.289 $\mathrm{t} / \mathrm{t}-\mathrm{Fe}(737 \mathrm{t} / \mathrm{d})$ なのてで融着層総重量は， $3287 \mathrm{t} / \mathrm{d}$ と なる、史際の重量は，酸素の分の補正がいるがこれを無 視する.

根部以外で $3287(\mathrm{t} / \mathrm{d}) \times 0.183=601 \mathrm{t} / \mathrm{d}(=25.1 \mathrm{t} / \mathrm{h})$ 根部では $3287(\mathrm{t} / \mathrm{d}) \times 0.817=2685 \mathrm{t} / \mathrm{d}(=111.9 \mathrm{t} / \mathrm{h})$ 
Table 4. Heat transfer quantity to softening-melting zone in one hour and Heat of fusion.

\begin{tabular}{|c|c|c|c|c|c|}
\hline $\begin{array}{c}\text { No. of } \\
\text { layer }\end{array}$ & at $\underset{\mathrm{g}=t_{\mathrm{m}_{0}}(\mathrm{~m})}{\text { Radius }}$ & $\begin{array}{c}\text { Heat transfer } \\
\text { quantity }(\mathrm{kcal} / \mathrm{h})\end{array}$ & $\begin{array}{l}\text { Melt-down } \\
\text { volume }\left(\mathrm{m}^{3}\right)\end{array}$ & $\begin{array}{c}\text { Heat of } \\
\text { fusion }(\mathrm{kcal} / \mathrm{t})\end{array}$ & Mean value \\
\hline $\begin{array}{l}3 \\
4 \\
5\end{array}$ & $\begin{array}{l}1.27 \\
1.34 \\
1.55\end{array}$ & $\begin{array}{l}3240 \\
5400 \\
6440\end{array}$ & $\begin{array}{l}0.08 \\
0.33 \\
0.50\end{array}$ & $\begin{array}{l}5.1 \times 10^{3} \\
2.0 \\
1.6\end{array}$ & $2.9 \times 10^{3}$ \\
\hline 6 & 1.80 & 6130 & 0.10 & 7.6 & \\
\hline 7 & 1.84 & 7080 & 0.11 & 8.0 & \\
\hline 8 & 1.89 & 8790 & 0.11 & 9.9 & \\
\hline 9 & 1.94 & 8850 & 0.09 & 12.2 & \\
\hline 10 & 1.97 & 11020 & 0.21 & 6.5 & \\
\hline 11 & 2.05 & 13240 & 0.22 & 7.5 & $8.6 \times 10^{3}$ \\
\hline 12 & 2.12 & 16070 & 0.16 & 12.5 & \\
\hline 13 & 2.19 & 20750 & 0.32 & 8.0 & \\
\hline 14 & 2.31 & 23520 & 0.08 & 36.7 & \\
\hline 15 & 2.33 & 29280 & 0.05 & 73.0 & \\
\hline 16 & 2.36 & 36170 & 0.34 & 12.2 & \\
\hline 17 & 2.50 & 40830 & 0.11 & 46.3 & $31.3 \times 10^{3}$ \\
\hline
\end{tabular}

である.

前報から 1 装入間隔の時間で，根部以外の溶け落ち量 は $3.13\left(\mathrm{~m}^{3} / \mathrm{ch}\right)$ ゆ元時間当たり $13.6\left(\mathrm{~m}^{3} / \mathrm{h}\right)$, 見掛けの比 重は, $(25.1 / 13.6)=1.85 \mathrm{t} / \mathrm{m}^{3}$ になる. この見掛け比重 は, 鉱石層の浻密度 2.0 と比較してもやや小さい值にな るが，溶け落ち量の推定の整合性からこの值を用いる.

Table 4 にこの值を用い各層の熱移行量と溶以落ち量か ら融着層重量当たりの見掛け溶解熱を示した。

\section{3 根上部融着層の溶解に関する検討}

これらの数值を調べてみるとほぼ 3 段階の值に分かれ ている.すなわち 5 層目までと 11 層目までとそれ以外の 層である.この理由は, 計算に用いた温度分布の推定が, 融着帯下部の值を用いていることにもあるが，Fig. 2 の温度分布と併記した還元率分布をみると，温度よりも 還元率の違いによつていると考えるほうがよい. 融着層 の先端部の還元率をみると $2 \sim 5$ 層は, 完全に還元率 50 〜70\% の範囲にありかつ 50\%に近い.6〜11 層につい ては, 一方は還元率 50～70\% からやや 70\% 以上, 他 方は先端部が，わずかに 70\% 以上になつており溶け落 ち長さが約 $0.6 \mathrm{~m}$ であることを考えれれは，ほほ $70 \%$ の 還元率の溶解熱を示していると考えてよい，12 凮以下 については，ほとんど 70\% 以上にある.そこでこれら の溶解熱は, 還元率の違いあるいは嗹元率の差による溶 け落ち温度の違いによる溶解熱を示していると考えたほ うがよい。

これらの数值について通常純鉄の溶解熱は $66 \mathrm{kcal} / \mathrm{kg}$ なので完全に還元が進行したときはこの值に近付くはず である.70\%以上のときは，この值の約 1/2 になつて いる. 正確な值は, 今後の検討が必要とされよ5. しか しこれらの関係は，大きな矛盾がないので，この溶解人 カニズムは，信頼性があるものと考える.
このほかに 精度向上のためには， $\Delta t_{\mathrm{s}}$, 総括伝熱係数 $h_{\mathrm{w}}$ の精度向上および非定常状態の解析があげられる.

\section{3. 融着帯根部における溶け落ちの検討}

融着带根部の溶け落ちは, 前章 $\cdots 2$ で述べた根より 上部の溶解と違つたメカニズムを考える必要がある．融 着帯根部は, 融着層の一端が炉壁に接触しているため融 着層間を通つて炉壁側にガスが流れない。このため溶け 落ちは根部の融着層群の先端がガスによつてなめられる よらに行われると考えられる，そこで広畑 1 高炉解体時 の根部に対してこのメカニズムを設定して解析しその結 果が現在の稼動中の高炉の根部に適用できるかどうかで このメカニズムが妥当であるか検討する.

\section{1 広畑 1 高炉解体時の根部容解メカニズムと 総括伝熱保数の補正}

根部の溶解について熱移行を知るためには，炉内特に レース・ウェイ近傍の状態把握が必要とされる．この点 については, 各所で精力的な研究が行われており, 詳細 な検討は，その後になされるべきであるがあえて本報に おいては，根部全体の全溶解量を求めるように次の仮定 をして誤差を伝熱係数の中に入れ他の高炉への応用を考 えてみた。

(仮定)

（1）熱の移行は，充填層の壁への伝熱に近似すると し, 理論燃焼温度と融着層の溶け落ち温度の差に比例す 万.

（2）伝熱面積は，根部融着層群全体を考え根部の上 層で下層の影になつている部分は除いて考える.このよ らに考えると Fig. 3 のように投影面積と一致する.

（3）総括伝熱係数 $h_{\mathrm{wc}}$ は，葛岡の式の関係に従うと した・代表径として炉床径を採用する・たたし葛岡の式の 




Fig. 3. Definition of conditions of heat transfer area and ore layer change in radius with "root" at Hirohata No. 1 blast furnace.

比例定数は, 解体高炉の調査結果に合うように修正する. 以上の仮定から根部の単位時間当たりの熱移行量は,

$$
Q_{\mathrm{c}}=h_{\mathrm{wc}} S_{\mathrm{c}} \cdot\left(T_{\mathrm{f}}-t_{\mathrm{m}_{0}}\right)
$$

で表わせる.また $\mathrm{t}$ 当たりの融着層の溶解熱量を $q_{\mathrm{T}}$ と すると $\left(Q_{\mathrm{c}} / q_{\mathrm{T}}\right)$ が $1 \mathrm{~h}$ に根部で溶解する量になる.

$3 \cdot 1 \cdot 1$ 総括伝熱係数の補正

広畑 1 高炉解体時の羽口条件のうち最も代表的な羽口 $(145 \phi)$ について娭討し総括伝熱係数を求める. 広畑 1 高炉解体時の融着帯根部は, 代表的羽口について 18 層 〜24層までであり平均 7 層の融着層が存在している. この根部の量のうち溶解すべき量は, 前節の結果から $112 \mathrm{t} / \mathrm{h}(25.6 \mathrm{t} /$ 層· $\mathrm{h})$, この時の伝熱面積, $45.03 \mathrm{~m}^{2}$ で 溶解しなければならない。

根部に与える熱量 $Q_{\mathrm{c}}$ は，操業条件から総括伝熱係数 $h_{\mathrm{w}}$ を未知とすると

$$
Q_{\mathrm{c}}=h_{\mathrm{wc}} \cdot 45.03 \cdot(2066-1420) \quad \text { となる．この }
$$

値が根部の溶解熱（溶解すべき融着層重量から計算した 值)に等しければ熱バランスが合ら。すなわち $\left(Q_{\mathrm{c}} / q_{\mathrm{T}}\right)$ が, $112 \mathrm{t} / \mathrm{h}$ にならねばならない、根部の溶解熱最とし て, 融着帯下部の値を使うと

$$
h_{\mathrm{wc}} \cdot 45.03 \cdot(2066-1420) / 31000=112
$$

から $h_{\mathrm{wc}}=119.3\left(\mathrm{kcal} / \mathrm{m}^{2} \cdot \mathrm{h} \cdot{ }^{\circ} \mathrm{C}\right)$ になる.

一方広畑 1 高炉解体時の羽口条件から $h_{\mathrm{wc}}$ を求めると $h_{\mathrm{wc}}=28.5$ となる. 葛岡の関係式のうち無次元項は, そ
のまま成立するとすれば式中の係数 0.62 を 2.59 にす ればよい. 求められた関係式は,

$$
h_{\mathrm{wc}}=2.59\left(\lambda_{\mathrm{g}} / D_{\mathrm{T}}\right)\left(D_{\mathrm{T}} \cdot G / \mu_{\mathrm{f}}\right)^{0.7}\left(C_{\mathrm{p}} \mu_{\mathrm{f}} / \lambda_{\mathrm{g}}\right)^{1 / 3}
$$

となる.なおこの係数の違いについては次のように考え られる，葛岡の式は，理想化された充媜層の管壁への総 括伝熱係数である.しかし本報のような融着帯根部につ いては必ずしも理想的な充填層ではない，炉中心部に炉 芯部が存在するとその部分のガスの流れは少なくなり， その結果根部と炉芯部の間を流れるガスの質量速度が増 加しコークスの充填度合も踈になる．伝熱係数は，平均 的にガスが流れる場合よりも大きくなる.さらにレース ウェイ部になるとガス温度が高温になりコークスの充填 度合もほとんどなくなることから対流伝熱よりも圧倒的 に放射伝熱によると考えたほうがよい。これらの単密な 取扱いは，炉下部の構造がはつきりとしなければならな いが，ここではこれらを全体としてとらえ，通常の総括 伝熱係数（対流伝熱と放射伝熱を含んだもの）を使つて まとめた.この意味でこの数式の使用範囲は，極度に限 定する必要がある.

もら一つの溶解条件は，滞溜時間である．融着帯根部 の一層が，先端から順次消隇するためには，根部の平均 滞溜時間が，一層を溶解する以上になる必要があるが， 通常この条件は, 満足している.

\section{2 君津 3 高炉への応用}

3.1 の広畑解体高炬の融着根部で得られた結果を君津

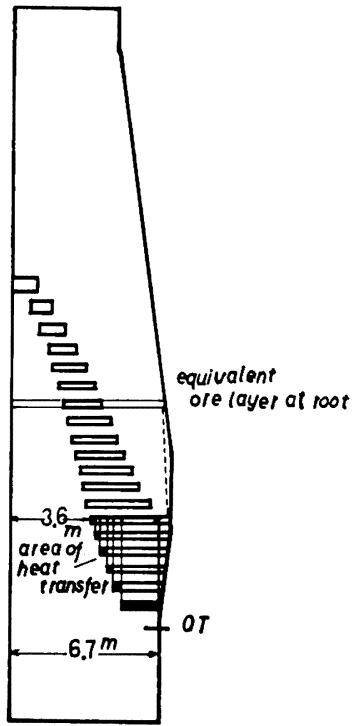

Fig. 4. Estimated softening-melting zone in Kimitsu No. 3 blast furnace on Feb. 10-17, 1975. 
Table 5. Operating results of Kimitsu No. 3 blast furnace on Feb. 10 17, (1975).

\begin{tabular}{c|c|c|c|c|c|c}
\hline Data & $\begin{array}{c}\text { Production } \\
(\mathrm{t}-\mathrm{Fe} / \text { day, t/day })\end{array}$ & $\begin{array}{c}\text { Slag Volume } \\
(\mathrm{t} / \mathrm{t}-\mathrm{Fe})\end{array}$ & $\begin{array}{c}\text { Blast Volume } \\
\left(\mathrm{Nm}^{3} / \mathrm{min}\right)\end{array}$ & $\begin{array}{c}\text { Blast Temp. } \\
\left({ }^{\circ} \mathrm{C}\right)\end{array}$ & $\begin{array}{c}\text { Humidity } \\
\left(\mathrm{g} / \mathrm{Nm}^{3}\right)\end{array}$ & $\begin{array}{c}\mathrm{O}_{2} \text { enrich } \\
\left(\mathrm{Nm}^{3} / \mathrm{h}\right)\end{array}$ \\
\hline Feb.10 17 & $9190(9705)$ & 0.347 & 6339 & 1311 & 5.4 & 7813 \\
\hline & $\begin{array}{c}\text { Coke Ratio } \\
(\mathrm{kg} / \mathrm{t}-\mathrm{p})\end{array}$ & $\begin{array}{c}\text { Oil Ratio } \\
(\mathrm{kg} / \mathrm{t}-\mathrm{p})\end{array}$ & $\begin{array}{c}\text { Sinter Ratio } \\
(\%)\end{array}$ & $\begin{array}{c}\text { Pellet Ratio } \\
(\%)\end{array}$ & $\begin{array}{c}\text { Number of Charge } \\
(\text { Number/day) }\end{array}$ & $\begin{array}{c}\text { Calculated Flame } \\
\text { temp. }\left({ }^{\circ} \mathrm{C}\right)\end{array}$ \\
\hline & 369 & 68.2 & 94 & 6 & 127 & 2352 \\
\hline
\end{tabular}

3 高炉について成立するかどらか検討する，Fig４は， 計算に用いた融着帯形状である。これは昭和 50 年 2 月 10〜17 日の平均的な 形状で前報の 静止モデルを君津 3 高炉に適用し，計算したシャフト圧力が実測のシャフト 王力に合致するよらに融着帯形状を求めたものである. この時の操業条件を Table 5 に示す. 根部の溶解能力 について広畑 1 高炉と同様の考方方で進める. 図から伝 熱面積 $S_{\mathrm{c}}$ は $100.3 \mathrm{~m}^{2}$ になる.この状態でどのくらい 溶解するか計算すると，融着層の溶解熱は前節から 31 $\mathrm{kcal} / \mathrm{kg}$-融着層，溶解温度は，原料が焼結鉱が $94 \%$ な ので広畑 1 高炉の解体時よりも溶け落ち温度を高く考兄 て $1450^{\circ} \mathrm{C}$ とし, 総括伝熱係数 $h_{\mathrm{wc}}$ は, 式(5)から求 めると $168.4 \mathrm{kcal} / \mathrm{m}^{2} \cdot \mathrm{h} \cdot{ }^{\circ} \mathrm{C}$ になる。溶解量は

$168.4 \times 100.3 \times(2352-1450) / 31000=491 \mathrm{t} / \mathrm{h}$ となる。

一方実際に溶解すべき量は，516 t/h 根部で溶解する 量は，前節と同様に Fig. 4 から $(6.2+7.3) / 2=6.75 \mathrm{~m}$ 位置の半径比の鉱石量から根部が成立するとすれば，根 部までに溶解した量は $3.6 \mathrm{~m} \phi /$ 層ゆえ $(3.6 / 6.75)^{2}=$ 0.284 根部で溶解すべき量は，全体の 0.714 から $516 \times$ $0.714=369 \mathrm{t} / \mathrm{h}$ になる。これは，溶解量とかなりよい 一致をしているといえよう。

根の滞溜時間については，当然のことながら十分あ る. 昭和 50 年 2 月の融着帯の推定は, 溶解能力を満足 した形状を与えて拈り，かつ広畑 1 高炉の解体結果とも 合致する正常な状態と推定される.

\section{3 根部溶解に関する考察}

広畑 1 高炉の解体結果をもとに君津 3 高炉の融着带根 部の溶解について検討した，計算には，いくつかの仮定 があるが，大筋は議論できよう。

根部の溶解能力は, $h_{\mathrm{wc}} \cdot S_{\mathrm{c}} \cdot\left(T_{\mathrm{f}}-t_{\mathrm{m}_{0}}\right)$ で計算される. 与えられた高炬において溶解能力を上年させるために は, ガス量の増加 $\left(h_{\mathrm{wc}} \infty G^{\mathbf{0 . 7}}\right)$ か理論燃焼温度の上昇を はかる必要がある. 50 年 2 月の君津 3 高炉の場合理論燃 焼温度は， $2352^{\circ} \mathrm{C}$ であつたが，これより約 $230^{\circ} \mathrm{C}$ 低 い2 $120^{\circ} \mathrm{G}$ 以下になれば溶解能力がなくなり高炉とし
て成立しなくなると考えられるるちろん原料性状が変 わり溶け落ち盜度 $t_{\mathrm{m}_{0}}$ が変われば，それに応じた溶解能 力にする必要がある.

炉腹, 朝顔のプロフィールに関係して炉腹が炉床径よ りも外㑡にある量が大きければ，溶解能力を増加させね ばならない。

溶解能力という点では問題にならなかつたが，根部の 高さに関係しては（根の層数に関係する）むしろ根部融 着層の加熱のための滞溜時間や融着帯を支える強さ，レ 一スウェイの吹抜けといら力学的な面の検討13)からも決 定する必要がある．また今後は，ここに用いた仮定の正 しさも含めて装入物の降下機構，コークスの加熱のされ 方，伝熱係数の精度向上を実験的に確かめることや計算 方法の改良で各数值の精度を上げたいと思つている.

最後に全般を通して原料性状の点から考察してみる. 高炉の軟化融着帯が，ガス分配と対応していることがわ かつてきているが，この報告にあるように原料の還元率 が低いと溶解熱量も少ないといら関係（計算の前提とし て溶け落ち温度一定のため見掛け溶解熱量が小さくつ たとも考えられる）や還元率と溶け落ち温度が関係すれ ば14), 原料性状によつて特に還元過程の履歴が融着帯形 状に大きな影響をおよぼすことは容易に想像できる。 し，ペレット・鉱石型のよらに還元率が低いと溶け落ち 温度が低いものは，考えているよりも頂層の高い融着帯 ができる、また炉の変動に伴つて還元状態が変化すると 融着帯が大きく変動する，一方焼結鉱のよらに還元率の 変化に対して溶け落ち温度の変化が小さいものは，炉の 変動に対して安定な融着帯が形成されると考えられる.

また溶け落ち温度の幅の広い原料は，この計算で得ら れている溶け落ち長さ（幅）よりも長くなり，コーク ス・スリット層を滴下物でふさぐようになり高灯の通気 性の点で好ましくない. 溶け落ち温度の幅が狭く, 温度 の高い原料は, 根上部の溶解が少なくなり, その分根部 の溶解量が増加するので, 根部の溶解能力を増やすアク ションが必要となる.

融着帯に影響を与えるものは単に高炉の物理的条件た 
けでなく原料性状とも密接に関係することから原料, 高 妒操業の両面から融着帯を検討することが必要である.

\section{4. 結言}

広畑解体 1 高炬の結果について軟化融着帯の根より上 部および根部の溶解メカニズムを設定し根より上部の融 着帯の見掛け溶解熱および根部の溶解量を求めた.

この結果 1) 根より上部の融着帯の溶解熱は, 還元率 の違いによつて上部還元率 $50 \%$ 附近で $3 \mathrm{kcal} / \mathrm{kg}$ 融着 帯, $70 \%$ 附近で $8.5 \mathrm{kcal} / \mathrm{kg}, 70 \%$ 以上の融着帯下部 で $31 \mathrm{kcal} / \mathrm{kg}$ の值になつた。この時の溶け落ち温度は $1420^{\circ} \mathrm{C}$ とした.

2)この溶解熱を用い根部の全溶解量を算出すると, 根部の総括伝熱係数を

$$
h_{\mathrm{wc}}=2.59 \times\left(\lambda_{\mathrm{g}} / D_{\mathrm{T}}\right)\left(D_{\mathrm{T}} \cdot G / \mu_{\mathrm{f}}\right)^{0.7}\left(C_{\mathrm{p}} \mu_{\mathrm{f}} / \lambda_{\mathrm{g}}\right)^{1 / 3}
$$

とすれば，広畑解体高炉の溶解条件を満足する．さらに この $h_{\mathrm{wc}}$ を用い，君津 3 高炉の通常操業時の推定融着帯 形状に適用した結果, 溶解条件を満足していることがわ かつた.この溶解機構により根部の溶解を説明できる可 能性を見出した。

今後は, 装入物の高温性状の解明を含め軟化融着帯が 諸条件の違いによつてどのように変わるかといら炉内現 象の解明と諸数值の精度を上げる必要があると考える.

最後に解析の一部について示唆をいただいた東北大学 八木助教授に深く感謝の意を表します。

\section{記 号}

$A_{0}$ : 単位充填層の伝熱面積 $\left(\mathrm{m}^{2} / \mathrm{m}^{3}\right)$

$C_{\mathrm{c}}, C_{\mathrm{p}}:$ コークスおよびガスの比熱 $\left(\mathrm{kcal} / \mathrm{kg} \cdot{ }^{\circ} \mathrm{C}\right)$

$d_{\mathrm{s}}:$ コークスの直径 $(\mathrm{m})$

$D_{\mathrm{T}}$ : 相当直径, 师床径 $(\mathrm{m})$

$F_{\mathrm{g}}$ : 質量供給速度 $(\mathrm{kg} / \mathrm{h})$

$G:$ ガスの質量速度 $\left(\mathrm{kg} / \mathrm{m}^{2} \cdot \mathrm{h}\right)$

$h_{\mathrm{p}}$ : ガスから粒子への伝熱係数 $\left(\mathrm{kcal} / \mathrm{m}^{2} \cdot \mathrm{h} \cdot{ }^{\circ} \mathrm{C}\right)$

$h_{\mathrm{w}}, h_{\mathrm{wc}}$ : ガスから融着層一の伝熱倸数, 根部における 伝熱倸数 $\left(\mathrm{kcal} / \mathrm{m}^{2} \cdot \mathrm{h} \cdot{ }^{\circ} \mathrm{C}\right)$

$k_{\mathrm{f}}$ : 熱伝導率 $\left(\mathrm{kcal} / \mathrm{m} \cdot \mathrm{h} \cdot{ }^{\circ} \mathrm{C}\right)=360 \cdot \mu_{\mathrm{f}}\left(C_{\mathrm{p}}+2.48 / \bar{M}\right)$

$l_{\mathrm{c}}$ : 融着層間コークスの㕌厚 $(\mathrm{m})$

$\bar{M}:$ 平均分子量 $(\mathrm{kg} / \mathrm{kg}-\mathrm{mol})$

$n: 1$ 時間の装入回数 $(1 / \mathrm{h})$

$Q_{1}, Q_{2}, Q_{c}$ : ガスの熱量 $(\mathrm{kcal} / \mathrm{h})$

$q, q_{\mathrm{T}}$ : ガスから固体への移動熱量 $(\mathrm{kcal} / \mathrm{h}), \mathrm{t}$ 当た り融着層の溶解熱 $(\mathrm{kcal} / \mathrm{t})$

$r:$ 师中心からの距離 $(\mathrm{m})$

$r_{0}, r_{1}, r_{m_{0}}$ : 融着層先端および $1 \mathrm{~m}$ 後の径方向の中心か
らの距離 $(\mathrm{m})$, 溶け落ち始める中心からの距 離 $(\mathrm{m})$

$S_{\mathrm{C}}:$ 根部の伝熱面積 $\left(\mathrm{m}^{2}\right)$

$T_{\mathrm{f}}, t_{\mathrm{g}}$ : ガスの理論燃焼温度, ガスの温度 $\left({ }^{\circ} \mathrm{C}\right)$

$t_{\mathrm{m}_{\mathrm{o}}}$ : 融着帯の溶け落ち温度 $\left({ }^{\circ} \mathrm{C}\right)$

$t_{\mathrm{S}_{0}}(r), t_{\mathrm{S}_{1}}(r)$ : 融着層間コークスの径方向温度分布と 1 層下の温度分布 $\left({ }^{\circ} \mathrm{C}\right)$

$\lambda_{\mathrm{g}}: k_{\mathrm{f}}$ に同し $\left(\mathrm{kcal} / \mathrm{m} \cdot \mathrm{h} \cdot{ }^{\circ} \mathrm{C}\right)$

$\rho_{\mathrm{C}}:$ 融着層の密度 $\left(\mathrm{t} / \mathrm{m}^{3}\right)$

$\phi_{\mathrm{S}}:$ 形状係数 (一)

$\mu_{\mathrm{f}}:$ ガスの粘性 $(\mathrm{kg} / \mathrm{m} \cdot \mathrm{h})=360(\mathrm{~g} / \mathrm{cm} \cdot \mathrm{s})$

物性定数（式(5)の計算に用いた值)

$C_{\mathrm{p}}: 0.360\left(\mathrm{kcal} / \mathrm{kg}^{\circ} \mathrm{C}\right), 0.360\left(\mathrm{kcal} / \mathrm{kg}^{\circ} \mathrm{C}\right) \quad($ 広畑 1 高炉，君津 3 高炬の計算に用いた値)

$D_{\mathrm{T}}: 8.5(\mathrm{~m}), 13.4(\mathrm{~m})$

$G: 3810\left(\mathrm{~kg} / \mathrm{m}^{2} \cdot \mathrm{h}\right), 7490\left(\mathrm{~kg} / \mathrm{m}^{2} \cdot \mathrm{h}\right)$

$\bar{M}: 26.8(\mathrm{~kg} / \mathrm{kg}-\mathrm{mol}), 26.0(\mathrm{~kg} / \mathrm{kg}-\mathrm{mol})$

$\lambda_{\mathrm{g}}: 0.107\left(\mathrm{kcal} / \mathrm{m}^{2} \cdot \mathrm{h} \cdot{ }^{\circ} \mathrm{C}\right), 0.109\left(\mathrm{kcal} / \mathrm{m}^{2} \cdot \mathrm{h} \cdot{ }^{\circ} \mathrm{C}\right)$

$\mu_{\mathrm{f}}: 0.2376(\mathrm{~kg} / \mathrm{m} \cdot \mathrm{h}), 0.2376(\mathrm{~kg} / \mathrm{m} \cdot \mathrm{h})$

\section{文 献}

1) $K$. Kodama, S. Hashimoto: Proc. ICSTIS, Tokyo, Sept. (1970), Part I, p. 12

2 ) 神原健二郎, 萩原友郎, 重見彰利, 近藤真一, 金 山有治, 若林敬一, 平本信義：鉄と鋼，62(1976), p. 535

3) 下村泰人, 西川 潔, 有野倰介, 片山 力, 肥田 行博, 磯山 正：鉄と鋼, 62(1976), p. 547

4 ) 佐々木稔, 斧 勝也, 鈴木 明, 奥野嘉雄, 吉沢 謙一，中村 隆：鉄と鋼，62(1976), p. 559

5 ) 小嶋鴻次郎, 西徹, 山口德二, 仲摩博至, 井 田四郎：鉄と鋼，62(1976)，p. 570

6 ) 佐々木寞太郎, 羽田野道春, 渡辺雅男, 下田輝久, 橫谷勝弘，伊東孝夫，横井 毅：鉄と鋼， 62 (1976), p. 580

7 ) 館充, 桑野芳一, 鈴木吉哉, 張 東植, 吳 平男, 松崎幹康：鉄と鋼，62(1976), p. 495

8 ) 梶川修二, 隅田 昇, 吉越英之, 福島 勤, 鴨志 田友男，福山辰夫：鉄と銅，59(1973)，A81

9 ) 伊沢哲夫, 三浦光敏, 里見弘次, 斎藤正紀, 宮本 健彦, 福島 勤, 古川 武: 鉄之鋼, 63(1977), S 446

10）近藤真一：第33，34回西山記念技術㛵座，p. 125 [日本鉄銅協会]

11) 研野雄二, 須賀田正泰, 安倍 勲, 中村 展: 鉄 と鋼, 65(1979), p.

12) 斧 勝也: 学位論交

13）鈴木驍一：第 $33 ， 34$ 回西山記念技術講座, p. 1 [日本鉄鋼協会]

14) $S$. Kondo, $M$. Sugata, and $T$. Sugiyama: Proc. ICSTIS, Suppl. Trans. ISIJ, 11(1971), p. 36 